\title{
プラズマナノ加工における表面ラフネスとリップル形成機構
}

\author{
斧 高一・津田博隆* ・ 中崎暢也・鷹尾祥典・江利口浩二 \\ 京都大学大学院工学研究科航空宇宙工学専攻 凿615-8540 京都府京都市西京区京都大学桂
}

（2013 年 7 月 14 日受付；2013 年 8 月 23 日掲載決定）

\section{Plasma Etch Challenges for Nanoscale ULSI Device Fabrication : Modeling and Simulation of Surface Roughening and Rippling during Plasma Etching of Si}

\author{
Kouichi Ono, Hirotaka Tsuda *, Nobuya NaKaZaKi, Yoshinori TaKaO and Koji Eriguchi \\ Kyoto University, Graduate School of Engineering, Department of Aeronautics and Astronautics, \\ Kyoto-daigaku Katsura, Nishikyo-ku, Kyoto 615-8540
}

(Received July 14, 2013 ; Accepted August 23, 2013)

\begin{abstract}
Atomic- or nanometer-scale surface roughness has become an issue to be resolved in the fabrication of nanoscale ULSI devices, because the roughness at feature sidewalls and bottom surfaces is responsible for the variability in transistor performance. This paper presents a numerical and experimental study of surface roughening during plasma etching of $\mathrm{Si}$ in $\mathrm{Cl}_{2}$, with emphasis being placed on modeling, analysis, and control of plasma-surface interactions concerned. A three-dimensional atomic-scale cellular model (ASCeM-3D) based on Monte Carlo (MC) algorithm exhibited nanoscale surface roughening and rippling in response to ion incidence angle onto surfaces. Experiments were conducted to demonstrate the validity of our ASCeM-3D model, and to investigate how to suppress and/or control the formation of surface roughness and ripples during plasma etching, where a classical molecular dynamic (MD) simulation for $\mathrm{Si} / \mathrm{Cl}$ and $\mathrm{Si} / \mathrm{SiCl}$ systems was also invoked to further understand atomistic mechanisms concerned.
\end{abstract}

KEYWORDS : plasma etching, surface roughening and rippling, line edge roughness, line width roughness, ULSI

\section{1.は じめ に}

プラズマを用いた微細加工（プラズマエッチング）は 今日, ULSI (ultra large scale integration) や MEMS (micro electro mechanical system）デバイス作製など先端技術 分野で不可欠のトップダウン微細加工プロセスであ る ${ }^{1)}$ 。ULSI デバイスの素子や回路パターンの寸法（溝 幅, 線幅, 孔径, 柱径など) は現在 30〜20 nm のレベ ルにあるが，今後数年の間に $10 \mathrm{~nm} レ$ レ゙となり，10 年後には数 $n m$ のデバイスも視野に入る ${ }^{2)}$ 。

トランジスタ形成にかかわるプロセスにおいて，たと えば $10 \mathrm{~nm}$ 幅のゲート加工において許容される電極形 状の加工寸法精度は $1 \mathrm{~nm}$ 以下である。また, 厚さ $2 \mathrm{~nm}$ 以下と薄い下地ゲート絶縁膜を削らない高い選択性も求

E-mail : ono@kuaero.kyoto-u.ac.jp

*現在 : (株) 東芝, Present address : Toshiba Corporation
められ, さらに, ゲート絶縁膜の下に広がる半導体基板 の変質 (ダメージ) 層も $1 \mathrm{~nm}$ 以下に抑える必要があ る。このように, $10 \mathrm{~nm}$ レベルのエッチングには, 原子 1〜数個の原子層レベルの高い加工精度が不可欠とな る3)。

プラズマエッチングには今後も引き続き，1微細パタ ーンの加工性（形状異方性と寸法精度，材料選択性）, (2)損傷性（ダメージ）とともに，それらの(3)チップ・セ ルサイズレベルでの微視的な均一性（パターン密度・寸 法・アスペクト比依存性), (4)ウエハスケールの巨視的 な均一性，および(5)大口径基板に対する生産性（プロセ ス速度, 制御性, 再現性)，の観点から不断の技術開 発・改善が求められ ${ }^{4)}$, 最近では, フィン型トランジス 夕（fin-type field effect transistor, FinFET : 3 次元立体構造 の電界効果型トタンジスタ, Tri ゲートトランジスタと もいう), 高誘電率 (high- $k$ ) ゲート絶縁膜やキャパシ 夕絶縁膜, メ夕ル電極, 低誘電率 (low- $k$ ) 層間絶縁膜 
など, 新しいデバイス構造 ${ }^{5,6)}$ や材料7)への対応も求めら れる。

今後のナノスケールのプラズマエッチング技術の高精 度化に打いて, プラズマと表面との相互作用（以下，プ ラズマ・表面相互作用とよぶ）に関するより詳細で高度 な理解と高精度な制御が一層重要となる ${ }^{8,9)}$ 。ナノスケ ールではプラズマから基板表面に入射する反応粒子の数 が少ない。たとえば, 表面 $1 \mathrm{~nm}^{2}$ を深さ $1 \mathrm{~nm}$ 加工する に際して表面に入射するイオンは<100 個程度であり (後述), プラズマ・表面相互作用の摇らぎが加工精度に 影響を及ぼすことも考えられる。

本稿では, $\mathrm{Cl}_{2}$ プラズマによる $\mathrm{Si}$ エッチングにおいて 生じる表面ラフネスについて, 形成メカニズムのモデリ ングとシミュレーション, ならびにその実験検証に関す る筆者らの最近の研究を紹介する ${ }^{8 \sim 15)} 。 \mathrm{Cl}_{2}$ や $\mathrm{HBr}$ プラ ズマは, ULSI の多結晶 (poly-) Si ゲート加工や, 結晶 (c-) Si 基板のフィン加工, シャロートレンチ加工など に执いて用いられる1)。

\section{2. プラズマエッチングにおける表面ラフネス}

プラズマエッチングによって基板表面のラフネスは増 大する ${ }^{16222 。}$ 。ナノスケールの微細トランジスタ形成で は, パターン底面のラフネスは底面の不均一性を生じ, 底面のラフネスが大きいと, 基板リセスやダメージによ ってトタンジスタ間の特性ばらつきを生じる ${ }^{23)}$ 。一方パ ターン側壁のラフネスは, ゲート電極などのライン端ラ フネス (line edge roughness, LER) を生じ, LER が大き いと, ライン幅ラフネス (line width roughness, LWR : ラ イン幅の奥行き方向の変動）が大きくなり, ライン幅す なわちゲート長に関してトランジス夕間の加工寸法がば らつき, しきい值電圧などについてトランジスタ間の特 性ばらつきを生じる ${ }^{5,24)}$ 。さらに, 3 次元立体構造の FinFET では, フィンの上面と側壁表面にトランジス夕 のチャネル（導電層）を形成するため, ゲート電極のみ ならずフィンの LER, LWR も問題となる ${ }^{5,6) 。}$

パターン側壁の LER は, リソグラフィー工程におけ るエッチングマスクの加工精度（マスク側壁端の凹凸が 被エッチング薄膜や基板のパターン側壁に転写される)

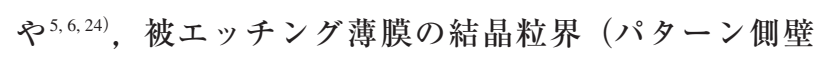
に露出した結晶粒界がエッチングされ，その凹凸がパ夕 ーン側壁底部に転写される）に依存する。Poly-Si ゲー

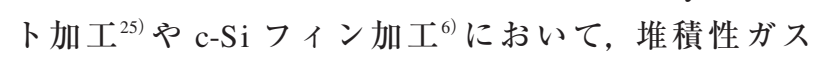
$\left(\mathrm{CF}_{4}\right)$ や反応生成物の堆積性が比較的強いエッチング ガス（HBr）の添加により側壁保護効果を増大して側壁 ラフネス減少に至る。一方, LER など表面ラフネスは, プラズマと被エッチング表面との直接的な相互作用にも
要因があると考えられるが, プラズマエッチングにおけ る表面ラフネス形成のメカニズムの理解は十分でない。 パターン側壁では特にマスク起因のラフネスとの峻別が 難しい。

\section{3. モデリング・シミュレーション}

プラズマエッチングによる微細加工形状進展につい て, 筆者らは, モンテカルロ (Monte Carlo, MC) 法を ベースとした原子スケールセルモデル (atomic-scale cellular model, ASCeM）を開発し, 2 次元モデル（ASCeM$2 \mathrm{D}$; 位置空間 2 次元・速度空間 3 次元）により,トレ ンチ加工における種々の形状異常や, 加工特性のパター ン幅依存性の発現メカニズムに関する研究を行ってき

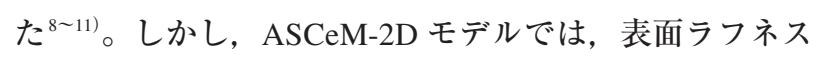
やパターン側壁の LER, LWR を再現できず, 3 次元モ デル（ASCeM-3D；位置・速度空間 3 次元）を新たに開 発した ${ }^{12 \sim 14)}$ 。

\subsection{ASCeM-3D モデル}

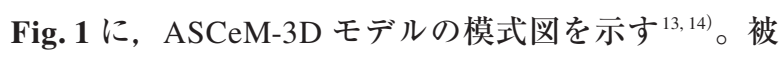
エッチング基板表面を, 基板 $\mathrm{Si}$ 原子 1 個を中心に含む 微小立方体七ルに分割し, 基板の上部空間も同じ大きさ の微小立方体セルに分割して解析領域を構成する。ここ で, ASCeM モデルを特徽づける微小セルの 1 辺は原子 スケール $L=\rho_{\mathrm{Si}}{ }^{1 / 3}=2.7 \AA$ であり $\left(\rho_{\mathrm{Si}}=5.0 \times 10^{22} \mathrm{~cm}^{-3}\right.$ は $\mathrm{Si}$ 基板の原子密度), エッチングに際してセルの変形は ないと仮定する。解析領域の断面は一辺 $50 \mathrm{~nm}$ の正方 形で, 基板は計算開始時（at $t=0 ） に$ 平坦な表面を有し 深さ $630 \mathrm{~nm}$ である（基板セル数 $185 \times 185 \times 2333 \approx 8 \times$ $10^{7}$ )。基板表面のイオン入射位置での局所表面垂線（lo-
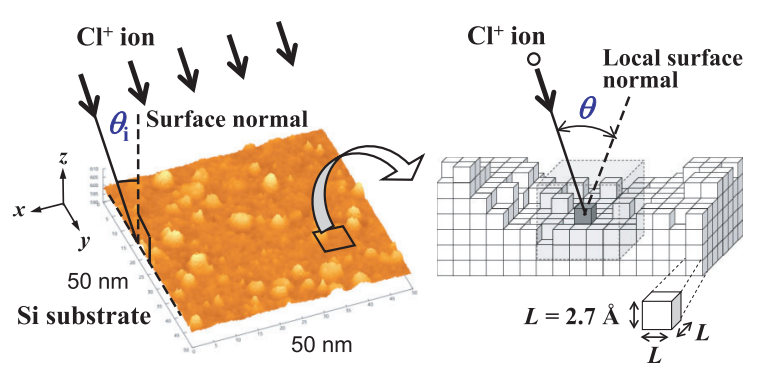

Fig. 1. (color online). Schematic of our Monte Carlo (MC) based, three-dimensional atomic-scale cellular model (ASCeM-3D) for simulating the feature profile evolution during plasma etching. The simulation domain is a square 50 $\mathrm{nm}$ on a side with an initial depth of $630 \mathrm{~nm}$, consisting of a number of small cubic cells of atomic size $L=2.7 \AA$. In the figure, $\theta_{\mathrm{i}}$ is the ion incident angle on substrate surfaces, while $\theta$ is the local ion incident angle on local feature surfaces thereon. 


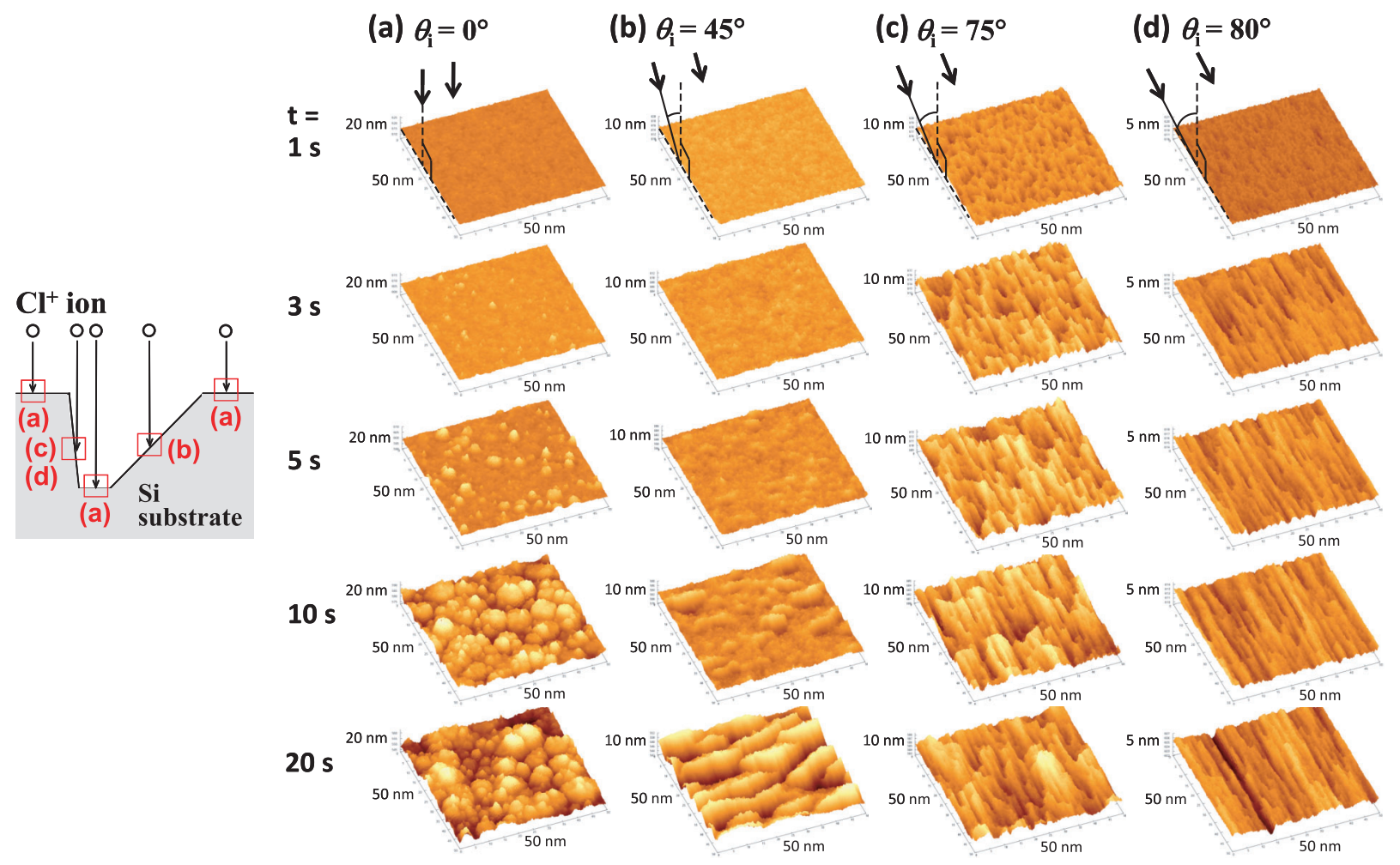

Fig. 2. (color online). Time evolution of surface features of $\mathrm{Si}$ etched in $\mathrm{Cl}_{2}$ plasma, simulated with $\mathrm{ASCeM}-3 \mathrm{D}$ for different ion incident angles of $\theta_{\mathrm{i}}=$ (a) $0^{\circ}$, (b) $45^{\circ}$, (c) $75^{\circ}$, and (d) $80^{\circ}$. Inset is a schematic of the situations of surface features corresponding to the respective $\theta_{\mathrm{i}}$. Input parameters for simulation were $:$ an ion energy $E_{\mathrm{i}}=100 \mathrm{eV}$, ion flux $\Gamma_{\mathrm{i}}{ }^{0}=$ $1.0 \times 10^{16} \mathrm{~cm}^{-2} \mathrm{~s}^{-1}$, and neutral-to-ion flux ratio $\Gamma_{\mathrm{n}}{ }^{0} / \Gamma_{\mathrm{i}}^{0}=100$, which are typical in high-density plasma etching environments.

cal surface normal）は，当該表面セルに関して周团 $5 \times 5$ $\times 5=125$ 個のセルにおける $\mathrm{Si}$ 原子の有無によって決め (modified four-point technique)，イオンによるエッチング 収率などの算出に供される（後述）。なお，この基板モ デルは Si 結晶構造を考慮しているものでなく, ASCeM は基板の結晶性に依存する現象を再現することはできな い。

$\mathrm{Cl}_{2}, \mathrm{Cl}_{2} / \mathrm{O}_{2}$ プラズマによる $\mathrm{Si}$ エッチングにおける入 射反応粒子として, イオン $\left(\mathrm{Cl}^{+}\right)$, 中性の反応種 $(\mathrm{Cl}$ 原 子), 保護膜形成堆積種 (反応副生成物: $\mathrm{SiCl}_{x}, \mathrm{SiCl}_{x} \mathrm{O}_{y}$ ), 保護膜形成反応種（O 原子）の 4 種類を考え，また被工 ッチング表面からの反応生成物 $\left(\mathrm{SiCl}_{x}, \mathrm{SiCl}_{x} \mathrm{O}_{y}\right)$ の脱 離を考慮する。ここで，基板原子や入射・脱離粒子はす べて質点として扱う。粒子輸送に関して, 解析領域の上 部空間（微細構造空間，真空）でほかの粒子との衝突は なく, 個々の粒子は微小時間 $\Delta t$ ごとに一定の微小距離 $L$ 動くとする。そして, 粒子が存在する位置のセルが基 板表面セルに隣接したところで，当該粒子は表面に到達 し入射と判断する。また，水平方向には周期境界条件を 課す。
$\mathrm{ASCeM}$ モデルでは, 中性反応種の吸着と反射（再放 出), 化学的エッチング, イオン誘起エッチング, 物理 的スパッタリング, 反応生成物・副生成物の表面への付 着と堆積など種々の表面反応過程が考慮され, 粒子輸送 とともに，MC 法を用いて解析される。ここで, 中性反 応種の基板表面への吸着・再放出では, 反応種の吸着 は，表面セルあたり $\mathrm{Cl}$ 原子 4 個までとし，再放出は表 面温度のもと等方的（拡散反射）と仮定する。保護膜形 成反応種の表面への吸着も同様であり，表面セルあたり $\mathrm{O}$ 原子は 2 個まで入る。反応生成物・副生成物の表面へ の付着・堆積では, Si 原子を中央に含む新たなセルを 基板表面セルに隣接して加えることにより表面（真空と 基板との界面）の移動を表す。

さらに，イオンの基板表面での反射（散乱）や内部へ の侵入を考虑する。入射イオンと基板原子との間の 2 体 ポテンシャル（ZBL［Ziegler-Biersack-Littmark］型）に もとづき，入射イオンの基板原子による古典的な弾性衝 突過程を連続的に計算し, 表面での反射や内部への侵入 を表す。このイオンの表面散乱過程の取り扱いは ASCeM モデルのもう一つの特徵であり, 表面への入射 
エネルギー $E_{\mathrm{i}}$ (表面散乱する場合は，入射と反射のエ ネルギー差 $\left.\Delta E=E_{\mathrm{i}}-E_{\mathrm{r}}\right)$ と，局所表面垂線に対する局 所入射角 (local angle of incidence) $\theta$ に基づき, 表面か らの反応生成物の脱離の確率, すなわちイオンアシスト 反応によるエッチング収率とスパッタリング収率を算出 し, 基板表面セルを取り除くことにより表面の移動を表 す。ここで, 反応生成物の脱離も, 表面温度のもと等方 的と仮定する。

\section{2 ASCeM-3D シミュレーション}

Fig. 2 に, $\mathrm{Cl}_{2}$ プラズマによる $\mathrm{Si}$ エッチングにおい て, イオンの基板表面への入射角度が $\theta_{\mathrm{i}}=0^{\circ}, 45^{\circ}, 75^{\circ}$, $80^{\circ}$ の場合について，表面形状の時間進展をシミュレー ションした結果を示す ${ }^{13,14)}$ 。ここで， $\theta_{\mathrm{i}}=0^{\circ}$ はパターン 底面や上面の状況, $\theta_{\mathrm{i}}=45^{\circ}, 75^{\circ}, 80^{\circ}$ はパターン側壁の 状況に対応する。これらの計算では, イオン入射エネル ギー $E_{\mathrm{i}}=e V_{\mathrm{sh}}=100 \mathrm{eV}$ ，イオンの入射エネルギーと熱運 動エネルギーとの比 $R=e V_{\mathrm{sh}} / k T_{\mathrm{i}}=200\left(k T_{\mathrm{i}}=0.5 \mathrm{eV}\right)$, イオンの入射フラックス $\Gamma_{\mathrm{i}}^{0}=1.0 \times 10^{16} \mathrm{~cm}^{-2} \mathrm{~s}^{-1}$, 中性 反応種とイオンの入射フラックス比 $\Gamma_{\mathrm{n}}{ }^{0} / \Gamma_{\mathrm{i}}{ }^{0}=100$ (圧力 10 mTorr 程度の高密度プラズマに相当), 中性粒子温度 $T_{\mathrm{n}}=500 \mathrm{~K}$ ，基板表面温度 $T_{\mathrm{s}}=320 \mathrm{~K}$, 基板中の不純物 （ドーパント）密度 $N_{\mathrm{e}}=1.0 \times 10^{18} \mathrm{~cm}^{-3}$ （ほぼ non-doped $\mathrm{Si}$ ）を仮定している。また，微細構造表面から脱離した 反応生成物 $\left(\mathrm{SiCl}_{x}\right)$ がその側壁や底面へ再入射して付 着・堆積する過程は付着確率 $S_{\mathrm{q}}=0.05$ として考虑して いるが，プラズマから基板表面への酸素や反応副生成物 の流入はないとしている $\left(\Gamma_{\mathrm{o}}{ }^{0}=0, \Gamma_{\mathrm{p}}{ }^{0}=0\right)$ 。

図において，（1）エッチング開始直後の微小な表面ラ フネスは，いずれの入射角度 $\theta_{\mathrm{i}}$ においてもランダムな 凹凸である。時間の経過とともに，(2) $\theta_{\mathrm{i}}=0^{\circ}$ (垂直入 射）ではランダムな凹凸が発達する，（3）的 $=45^{\circ}$ では， $t>5 \mathrm{~s}$ あたりからイオン入射に直交する方向に伸長する 凸構造が表れ，時間とともにリップル状（波状）の周期 構造が顕著になる（リップルの波長は〜 $10 \mathrm{~nm}$ ), ( 4 ) $\theta_{\mathrm{i}}$ $\geq 75^{\circ}$ (斜入射) では，比較的早い時間から $(t>1 \mathrm{~s})$ イ オン入射に平行な方向に伸長する細かいリップルが現れ 時間とともに顕著になる，ことがわかる。さらに，（5） 表面ラフネスの大きさや形状ならびに周期構造は, イオ ン入射角度 $\theta_{\mathrm{i}}$ とエッチング時間 $t$ のみならず，入射エネ ルギー $E_{\mathrm{i}}$, 中性反応種, 反応副生成物 $\left(\mathrm{SiCl}_{x}\right)$, 酸素と イオンの入射フラックス比 $\Gamma_{\mathrm{n}}{ }^{0} / \Gamma_{\mathrm{i}}{ }^{0}, \Gamma_{\mathrm{p}}{ }^{0} / \Gamma_{\mathrm{i}}{ }^{0}, \Gamma_{\mathrm{o}}{ }^{0} / \Gamma_{\mathrm{i}}{ }^{0}$, 基板表面温度 $T_{\mathrm{s}}$ ，イオン入射角度分布 $\Delta \theta_{\mathrm{i}}$ ，イオン表面 散乱，などに依存する，こともわかった ${ }^{14)}$ 。

このようなイオン入射角度に依存する表面ラフネスの 発現は, 希ガスイオンビーム $\left(E_{\mathrm{i}}=\right.$ 数 $100 \mathrm{eV}$ 数 $\left.\mathrm{keV}\right)$ と Si との相互作用において知られ, 実験・理論両面か
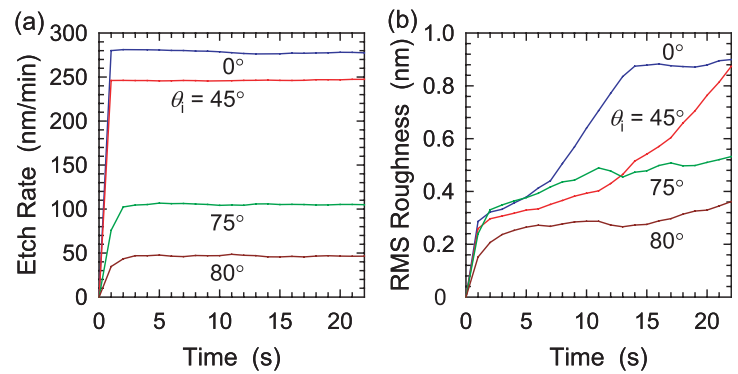

Fig. 3. (color online). Time evolution of the (a) etch rate and (b) root-mean-square (RMS) surface roughness for different ion incident angles $\theta_{\mathrm{i}}$, derived from the simulations of Fig. 2.

ら機構解明にかかわる活発な研究が行われている ${ }^{26 ~ 28) 。 ~}$ また，応用的にも，イオンビームによるナノ構造形成法 として関心が高い ${ }^{28)}$ 。

一方，プラズマエッチングでは，パターン側壁におけ るイオン入射が斜入射であり，イオン入射角度に依存す るラフネスはLER, LWR とも梁くかかわると考えられ るが，実際のプラズマエッチングでは，マスク側壁端ラ フネスに起因するパターン側壁ラフネスと，プラズマ起 因の側壁ラフネスとの区別が難しいこと，また，平坦基 板では, 表面シースの存在のため基板表面へのイオン斜 入射の実験が難しいことから，イオン入射角度に依存す るラフネス形成に関する実験的・理論的研究は極わずか である ${ }^{19,21,22) 。 ~}$

Fig. 3 に, Fig. 2 のミミュレーション結果から算出し たエッチング速度と, 表面の二乗平均 (rout-meansquare roughness, RMS）ラフネスの時間進展を示す。図 において，（ｉ）ER はエッチング開始後すぐに定常值を 示すが，RMS は，少しの誘導時間（induction time, $t<5$ ) の後，時間とともに発達することがわかる（RMS は， $\theta_{\mathrm{i}}=0^{\circ}$ では $t<20 \mathrm{~s}, \theta_{\mathrm{i}}=45^{\circ}$ では $t<60 \mathrm{~s}$ でほぼ定常，斜 入射 $\theta_{\mathrm{i}} \geq 75^{\circ}$ では $t>120 \mathrm{~s}$ 以降もまだ増大 $\left.{ }^{13)}\right)$ 。さらに, (ii) 斜入射 $\theta_{\mathrm{i}} \geq 75^{\circ}$ においてイオン入射方向と平行に形 成される媣い溝（たとえば，Fig. $2(\mathrm{~d}), \theta_{\mathrm{i}}=80^{\circ}, t=20$ s）は計算の再現性にそしいこともわかった ${ }^{14)}$ 。深い溝 形成の有無は, ASCeM における乱数 (確率過程) に起 因すると考えられるが，実際のプラズマエッチングのパ ターン側壁でも同様な現象が生じていると推測される。

ASCeM は MC 法をべースとしたシミュレーションモ デルであり，基板表面に入射する反応粒子のパラメー夕 （イオンや中性粒子の入射位置, 角度, エネルギー）や 反応粒子と基板表面との相互作用（表面反応やイオン表 面散乱過程）の決定に用いる乱数を通して，プラズマ・ 表面相互作用の摇らぎの効果が考慮されていることにな る。先に述べたように，ナノスケールの表面に入射する 


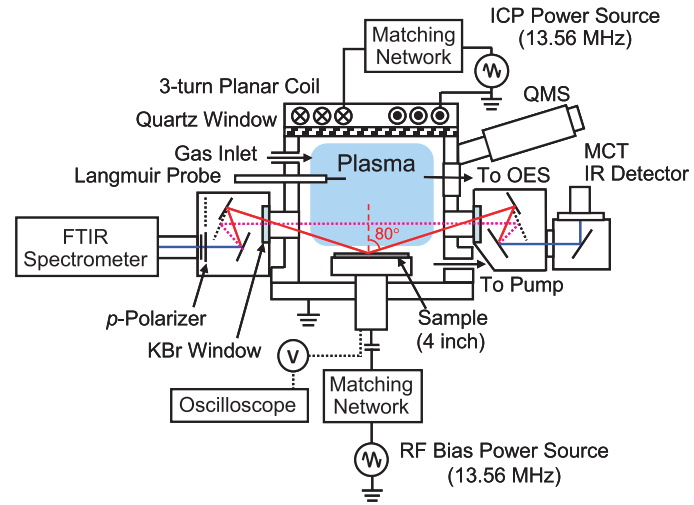

Fig. 4. (color online). Experimental setup for plasma etching using an inductively coupled plasma (ICP) reactor, including several plasma and surface diagnostics employed.

反応粒子の数は少ない（Fig. 2 に扔いて, 基板表面 $A=1$ $\mathrm{nm}^{2}$ に入射するイオンの数は $\Gamma_{\mathrm{i}}{ }^{0} A=1 \times 10^{2} \mathrm{~s}^{-1}, E R=$ $100 \mathrm{~nm} / \mathrm{min}$ とすると, 深さ $1 \mathrm{~nm}$ 加工する時間 $\Delta T$ の間 の入射イオンは $\Gamma_{\mathrm{i}}^{0} A \Delta T=60$ 個)。したがって, エッチ ング開始直後の誘導時間の間のランダムな微小表面ラフ ネス形成は，ナノスケールでの入射反応粒子パラメータ やその表面との相互作用の空間不均一性に依るもの (stochastic roughening) であろう。

しかし，その後のラフネスの発達や，イオン入射角度 に依存するリップル形成に関するメカニズムの理解は, 摇らぎの効果も含めて未だ十分でない。前者に関して は16 21), 微小ラフネス表面でのイオン散乱, 中性反応 種の再放出, 保護膜形成の効果, 一方後者に関して は19,21,22)，エッチング・スパッタリング収率のイオン入 射角度依存性, 中性反応種の表面拡散（マイグレーショ ン), イオンチャネリングの効果, などが議論されてい る。

\section{4. 実験}

Fig. 4 に, 誘導結合型高周波プラズマ (inductively coupled plasma, ICP) 装置（チェンバー直径 $25 \mathrm{~cm}$, 高さ $25 \mathrm{~cm}$ 。基板ステージ直径 $10 \mathrm{~cm}$ ）を用いた $\mathrm{Cl}_{2}$ プラズマ による Si エッチング実験の概要を示す ${ }^{(4)}$ 。ここで，プ ラズマ生成の高周波 (radio frequency, $\mathrm{rf}$ ) 電力 $P_{\mathrm{ICP}}=450$ $\mathrm{W}(13.56 \mathrm{MHz})$, 基板ステージの $\mathrm{rf}$ バイアス電力 $P_{\mathrm{rf}}=$ $0-200 \mathrm{~W}(13.56 \mathrm{MHz}), \mathrm{Cl}_{2}$ ガス流量 $F_{0}=20 \mathrm{sccm}$, ガ ス圧力 $P_{0}=20 \mathrm{mTorr}$ であり, エッチングサンプルとし て Si $(100)$ 基板を用いた $(n$ 型，比抵抗 $\rho \approx 10,0.02$ $\Omega \cdot \mathrm{cm}$, 希フッ酸洗浄, $R M S \approx 0.11 \mathrm{~nm})$ 。エッチング時 間 $2 \mathrm{~min}\left(\right.$ 最初 $10 \mathrm{~s}$ は $P_{\mathrm{rf}}=30 \mathrm{~W}$ のブレークスルーステ ップ）の後, 段差計（stylus gauge）を用いてエッチング
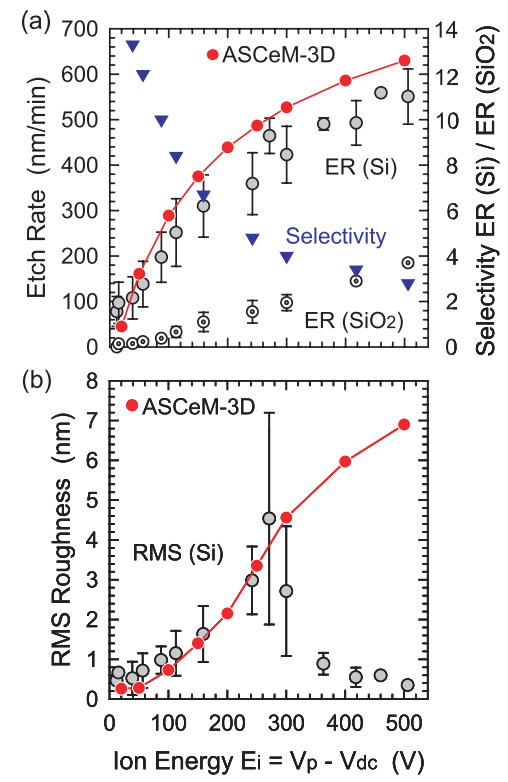

Fig. 5. (color online). (a) Etch rates (ERs) of $\mathrm{Si}$ and $\mathrm{SiO}_{2}$ and etch selectivity of $\mathrm{Si}$ over $\mathrm{SiO}_{2}$, and (b) root-mean-square roughness $(R M S)$ of $\mathrm{Si}$ as a function of ion incident energy $E_{\mathrm{i}}=V_{\mathrm{p}}-V_{\mathrm{dc}}$, experimentally obtained in ICP $\mathrm{Cl}_{2}$ plasma etching of $\mathrm{Si}$, where $V_{\mathrm{p}}$ is the plasma potential and $V_{\mathrm{dc}}$ is the dc self-bias voltage at the wafer stage. Also shown are the ERs and $R M S \mathrm{~s}$ of $\mathrm{Si}$ at $t=120 \mathrm{~s}$, obtained through ASCeM-3D simulation of etching for different $E_{\mathrm{i}}=20-500 \mathrm{eV}$ with $\theta_{\mathrm{i}}=$ $0^{\circ}$ (normal ion incidence) as shown in Fig. 2.

深さを測定し, エッチング速度 $E R$ （=深さ 算出した。また，原子間力顕微鏡 (atomic force microscopy，AFM）を用いて表面の二乗平均ラフネス $R M S$ を 測定した。実験では, 熱酸化膜基板 $\left(\mathrm{SiO}_{2}\right.$ 厚さ $\left.100 \mathrm{~nm}\right)$ も用い, $\mathrm{Si} / \mathrm{SiO}_{2}$ エッチング選択比も求めた。さらに, エッチング中のプラズマ状態を, 発光分光 (optical emission spectroscopy, OES), フーリエ変換赤外透過吸収 分光 (Fourier transform infrared-transmission absorption spectroscopy, FTIR-TAS), 四重極質量分析 (quadrupole mass spectrometry, QMS）を用いて，また，基板表面状 態を, FTIR 高感度反射吸収分光（FTIR-reflection absorption spectroscopy, FTIR-RAS）を用いてモニターし, 静電 プローブを用いてプラズマの電子密度・温度, イオン密 度, およびプラズマ電位 $\left(V_{\mathrm{p}}\right)$ を, 電圧プローブを用い て基板ステージの直流自己バイアス電圧 $\left(V_{\mathrm{dc}}\right)$ を測定 した。

Fig. 5 に, ICP-Cl 2 プラズマエッチング害験により得 られたエッチング速度 $E R$, 選択比, および表面ラフネ ス $R M S$ のイオン入射エネルギー $E_{\mathrm{i}}$ 依存性を示す ${ }^{14)}$ 。図 中, エラーバーは, 種々のエッチングサンプル（基板比 抵抗, 洗浄プロセス）に対する実験データ点のばらつき 


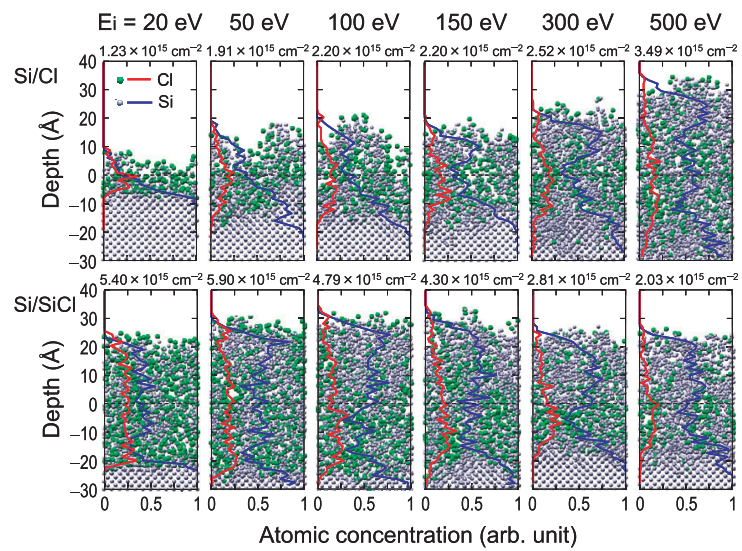

Fig. 6. (color online). Side views of the $\mathrm{Si}(100)$ surface after 2000 impacts of $\mathrm{Cl}$ and $\mathrm{SiCl}$ beams, together with the depth profile of $\mathrm{Cl}$ and $\mathrm{Si}$ atoms therein, obtained through classical molecular dynamics (MD) simulation of etching for $\mathrm{Si} / \mathrm{Cl}$ and $\mathrm{Si} / \mathrm{SiCl}$ systems with different beam energies of $E_{\mathrm{i}}=20-500$ $\mathrm{eV}$ and $\theta_{\mathrm{i}}=0^{\circ}$ (normal beam incidence). The simulation cell has a square $32.58 \AA$ on a side with an initial depth of $26 \AA$. Inset is the total coverage or areal density of $\mathrm{Cl}$ atoms therein.

を表す。ここで，基板表面へのイオン入射エネルギーは $E_{\mathrm{i}}=V_{\mathrm{p}}-V_{\mathrm{dc}}$ として算定した。図に扔いて, $E_{\mathrm{i}}$ の増大と ともに, (1) エッチング速度 $E R(\mathrm{Si}), E R\left(\mathrm{SiO}_{2}\right)$ は増大 し，選択比 $E R(\mathrm{Si}) / E R\left(\mathrm{SO}_{2}\right)$ は低下する $(\infty \rightarrow 2.8)$, 一 方，（2） Si 表面ラフネス RMS は， $E_{\mathrm{i}} \approx 250 \mathrm{eV}$ あたりま で増加するが, $E_{\mathrm{i}}>250 \mathrm{eV}$ では減少する, ことがわか る。

さらに, Fig. 5 に, ASCeM-3D シミュレーションによ り求めた $E R(\mathrm{Si}), R M S($ at $t=120 \mathrm{~s})$ を示す。計算は, イ オン入射角度を $\theta_{\mathrm{i}}=0^{\circ}$ (垂直入射)，イオン入射エネル ギーを $E_{\mathrm{i}}=20-500 \mathrm{eV}$ としたものであり，そのほかの 計算条件は Fig. 2, と同じである。害験と ASCeM-3D を 比較すると, ( 3 ) ASCeM-3D は, $E R(\mathrm{Si})$ vs $E_{\mathrm{i}}\left(E_{\mathrm{i}}<500\right.$ $\mathrm{eV})$ および $R M S$ vs $E_{\mathrm{i}}\left(E_{\mathrm{i}}<250 \mathrm{eV}\right)$ の関係を再現する が (ER, RMSは $E_{\mathrm{i}}$ とともに增大), $R M S$ vs $E_{\mathrm{i}}\left(E_{\mathrm{i}}>250\right.$ $\mathrm{eV})$ の関係は再現しないことがわかる。 $E_{\mathrm{i}}>250 \mathrm{eV} に$ おける RMS は, 実験では $E_{\mathrm{i}}$ の増大とともに減少に転じ るが, ASCeM-3D では増加し続ける。この比較により, ( i ) ASCeM-3D モデルはプラズマエッチングにおける 低いイオン入射エネルギー条件下 $\left(E_{\mathrm{i}}<250 \mathrm{eV}\right)$ の 3 次 元微細表面形状進展を再現できる, といえる。一方, (ii) 高いイオン入射エネルギー $\left(E_{\mathrm{i}}>250 \mathrm{eV}\right)$ において ASCeM-3D は実験を再現できない。図のシミュレーシ ヨンに考虑されていない基板表面温度上昇の効果, 中性 反応種の表面マイグレーション, 基板表面原子の再配 置，プラズマから基板表面に入射する短波長光や反応副
生成物，などの影響が考えられる。

プラズマ中のエッチング反応副生成物の密度は, $E_{\mathrm{i}}$ が増大すると $E R$ とともに増大する ${ }^{14)}$ 。実際, Fig. 5 の 穾験条件下の FTIR-TAS 測定によると, 反応副生成物と エッチングガス分子の密度比は, $E_{\mathrm{i}}>300 \mathrm{eV}$ に打いて $\left[\mathrm{SiCl}_{4}\right] /\left[\mathrm{Cl}_{2}\right]>0.1$ に達する。しかし, ASCeM-3D にお いて, 副生成物 $\mathrm{SiCl}_{x}$ の入射フラックス $\Gamma_{\mathrm{p}}{ }^{0}$ を増大させ ると, $E R$ は減少し $R M S$ は増大するが, 実験における $R M S$ vs $E_{\mathrm{i}}\left(E_{\mathrm{i}}>250 \mathrm{eV}\right)$ の関係は再現できなかった。一 方, QMS 測定（ionizer switched off）によると, 反応副 生成物イオンとガス分子イオンの密度比は, $E_{\mathrm{i}}>250$ $300 \mathrm{eV}$ において $\left[\mathrm{SiCl}^{+}\right] /\left[\mathrm{Cl}_{2}{ }^{+}\right],\left[\mathrm{SiCl}_{3}{ }^{+}\right] /\left[\mathrm{Cl}_{2}{ }^{+}\right]>1$ で あり，基板表面への入射イオンは $\mathrm{SiCl}^{+}, \mathrm{SiCl}_{3}{ }^{+}$の方が 多い状況になる。しかし, ASCeMにおいて副生成物イ オン $\mathrm{SiCl}_{x}{ }^{+}$の入射を考慮することは，モデルの基本仮 定（基板セルが含む $\mathrm{Si}$ 原子は 1 個，セルは変形しない) を損なうことになり，現在のモデルでは不可能である。

Fig. 6 に, $\mathrm{Cl}^{+}, \mathrm{SiCl}^{+}$イオンを $\mathrm{Si}(100)$ 基板表面に垂 直入射した場合の古典的分子動力学 (molecular dynamics, MD) シミュレーション結果を示す $\left(E_{\mathrm{i}}=20-500\right.$ $\mathrm{eV}, \theta_{\mathrm{i}}=0^{\circ}$, after 2000 impacts ${ }^{15)}$ 。シミュレーションセ ルの断面は一辺 $32.58 \AA$ の正方形であり, 基板表面の 1 層（monolayer, $\mathrm{ML}$ ）は 72 個の $\mathrm{Si}$ 原子を含み $\left(6.7 \times 10^{14}\right.$ atoms $\left./ \mathrm{cm}^{2}\right)$, 基板は計算開始時に深さ $26 \AA$ として 20 ML（1440 個）の Si 原子を含む。ここで，イオンは電 荷のない高速中性粒子ビームとして扱い, $\mathrm{Cl}$ と $\mathrm{Si}$ との 相互作用には, 改良型 SW（Stillinger-Weber）ポテンシ ヤルを用いる29,30)。また, セル底部の Si 原子は固定, 水平方向には周期境界条件が課されるが, エッチングの 進展に応じて，セル底部から $\mathrm{Si}$ 原子層を継ぎ足し, $\mathrm{Si}$ 原子層〜 $20 \mathrm{ML}$ 程度を維持する。図において, $\mathrm{Cl}$ ビー ム入射の場合, $E_{\mathrm{i}}$ の増大とともに, 表面反応層 $\left(\mathrm{SiCl}_{x}\right)$ 層の厚さが増大し, $\mathrm{Si}$ エッチング収量も増大する。一 方, $\mathrm{SiCl}^{+}$ビーム入射の場合, $E_{\mathrm{i}}<300 \mathrm{eV}$ では $\mathrm{SiCl}_{x}$ 層 の堆積が生じ, $E_{\mathrm{i}}>300 \mathrm{eV}$ に扔いてエッチングに転じ る。上の Fig. 5（b）に示した実験に扔ける Si 表面粗さ $R M S$ vs $E_{\mathrm{i}}\left(E_{\mathrm{i}}>250 \mathrm{eV}\right)$ の挙動（ $E_{\mathrm{i}}$ の増大とともに $R M S$ 減少）は，イオン入射エネルギー $E_{\mathrm{i}}$ の増大に伴う 入射イオン種の変化 $\left(\left[\mathrm{SiCl}^{+}\right],\left[\mathrm{SiCl}_{3}{ }^{+}\right]>\left[\mathrm{Cl}_{2}{ }^{+}\right]\right)$に 起因すると考えているが, メカニズムの理解にはあと少 しの解析が必要である。

\section{5. を と め}

プラズマエッチングに扔ける表面ラフネスは, ナノス ケールの微細デバイス作製プロセスにおいて, 加工寸法 のばらつきを生じ, 素子間の特性ばらつきに至るため, 
その形成機構の理解と制御法の構築が強く求められる。 本稿では, $\mathrm{Cl}_{2}$ プラズマによる $\mathrm{Si}$ エッチングにおける表 面ラフネス形成について, プラズマ・表面相互作用のモ デリングとシミュレーション, ならびにその実験検証に 関する筆者らの最近の研究を紹介した。ASCeM-3D シ ミュレーションから明らかになった基板表面へのイオン 入射角度に依存して変化する表面ラフネスの様子（入射 角の増大とともに, ランダムな凹凸 $\rightarrow$ ラン入入射に直行 方向に伸長するリップル $\rightarrow$ イン入射に平行方向に伸長 するリップル）は，パターン側壁の LER, LWRの再現 という実用的観点のみならず, ナノスケールでのプラズ マ・表面相互作用の特徵（入射反応粒子の数が少ないこ とに基づく相互作用の摇らぎなどの影響）にかかわる機 構解明という学術的観点からも興味深い。

ASCeM-3D により示された諸現象の実験検証と発現 メカニズム理解に関する研究が, MD シミュレーション の支援の下現在進行中である。ASCeM-3D と実験との ラフネスの矛盾解明（高エネルギーイオン垂直入射の場 合), プラズマシースの制御による周期的リップル構造 発現の実験実証 (イオン斜め入射の場合), ラフネスや リップルの時間発展のメカニズムに関する総合的理解, などである。さらに, これらの理解に基づき, 従来の側 壁保護効果に依らない表面ラフネスやリップルの制御 法, ひいてはプラズマエッチングにおけるナノ加工精度 向上のプロセス指針の構築を進めていきたいと考えてい る。

\section{謝辞}

本研究は科学研究費補助金新学術領域研究「プラズマ とナノ界面の相互作用に関する学術基盤の創成」の下で 行われたものであり, 津田博隆は日本学術振興会特別研 究員（2011～12 年度 DC2）であった。

\section{文献}

1) H. Abe, M. Yoneda and N. Fujiwara : Jpn. J. Appl. Phys. 47, 1435 (2008).

2) International Technology Roadmaps for Semiconductors (ITRS) 2011 Edition [http : //www.itrs.net]

3) K.J. Kanarik, G. Kamarthy and R.A. Gottscho : Solid State Technol. 55, 3, 15 (2012).

4) 斧高一他: プラズマ・核融合学会誌 85,163 (2009).

5) K. Patel, T.-J. King Liu and C.J. Spanos : IEEE Trans. Electron Devices 56, 3055 (2009).
6) E. Altamirano-Sánchez, V. Paraschiv, M. Demand and W. Boullart : Microelectron. Eng. 88, 2871 (2011).

7) 岩井 洋他: “ナノエレクトロニクスにおける絶縁 超薄膜技術一成膜技術と膜 - 界面の物性科学—” ( 工 ヌ・ティー・エス社, 2012).

8) K. Ono, H. Ohta and K. Eriguchi : Thin Solid Films 518, 3461 (2010).

9) 斧 高一: 化学工業 61, 457 (2010).

10) Y. Osano and K. Ono : J. Vac. Sci. Technol., B 26, 1425 (2008).

11) H. Tsuda, M. Mori, Y. Takao, K. Eriguchi and K. Ono : Jpn. J. Appl. Phys. 49, 08JE01 (2010).

12) H. Tsuda, H. Miyata, Y. Takao, K. Eriguchi and K. Ono : Jpn. J. Appl. Phys. 50, 08JE06 (2011).

13) H. Tsuda, Y. Takao, K. Eriguchi and K. Ono: Jpn. J. Appl. Phys. 51, 08HC01 (2012).

14) H. Tsuda, N. Nakazaki, Y. Takao, K. Eriguchi and K. Ono : Jpn. J. Appl. Phys. 53, (2014), submitted.

15) 中崎暢也, 鷹尾祥典, 江利口浩二, 斧 高一: 2013 年 秋季第 74 回応用物理学学術講演会, 18a-C2-7.

16) R. Pétri, P. Brault, O. Vatel, D. Henry, E. André, P. Dumas and F. Salvan : J. Appl. Phys. 75, 7498 (1994).

17) J.T. Drotar, Y.-P. Zhao, T.-M. Lu and G.-C. Wang : Phys. Rev. B 62, 2118 (2000).

18) G. Kokkoris, V. Constantoudis, P. Angelikopoulos, G. Boulousis and E. Gogolides: Phys. Rev. B 76, 193405 (2007).

19) Y. Yin and H.H. Sawin : J. Vac. Sci. Technol., A 26, 151 (2008).

20) M. Martina and G. Cunge : J. Vac. Sci. Technol., B 26, 1281 (2008).

21) W. Guo and H.H. Sawin : J. Phys. D : Appl. Phys. 42, 194014 (2009).

22) J.J. Végh and D.B. Graves : Plasma Sources Sci. Technol. 19, 045005 (2010).

23) K. Eriguchi, Y. Takao and K. Ono : J. Vac. Sci. Technol., A 29, 041303 (2011).

24) X. Sun and T.-J. King Liu : IEEE Trans. Semicond. Manuf. 23, 311 (2010).

25) J. Thiault, J. Foucher, J.H. Tortai, O. Joubert, S. Ladis and S. Pauliac: J. Vac. Sci. Technol., B 23, 3075 (2005).

26) W.L. Chan and E. Chason : J. Appl. Phys. 101, 121301 (2007).

27) T.K. Chini, D.P. Datta and S.R. Bhattacharyya : J. Phys. : Condens. Matter 21, 224004 (2009).

28) S.A. Pahlovy, S.F. Mahmud, K. Yanagimoto and I. Miyamoto : J. Vac. Sci. Technol., A 29, 021015 (2011).

29) H. Ohta, T. Nagaoka, K. Eriguchi and K. Ono: Jpn. J. Appl. Phys. 48, 020225 (2009).

30) T. Nagaoka, H. Ohta, K. Eriguchi and K. Ono : Jpn. J. Appl. Phys. 48, 070219 (2009). 